синтеза должен стать индивид (актор), а не общественные законы или структуры. В этом случае круг представителей «новой биографической истории» сужается до одного Ж. Ле Гофрфа.

Последнее ни в коей мере не умаляет значения труда Ж. Ле Гоффа, предложившего новую модель исторического исследования, позволяющую снять противоречие между структурой и индивидом, между макроисторией и микроисторией. Преодоление им «биографической иллюзии» на основе идей П. Бурдье не просто активизировало научный интерес к биографии, но поставило на повестку дня вопрос обновления предмета исторического исследования. Другое дело, что восприятие научным историческим сообществом «Людовика IX Святого» как, безусловно, новой парадигмы потребует времени.

1. Бурдье П. Биограсрическая иллюзия / пер. Е. Ю. Мещеркиной // Интер. 2002. № 1. С. 75-81.

2. Нечухрин А. Н. Теоретико-методологические основы российской позитивистской историографрии (80-е гг. XIX в. 1917 г.). Гродно : ГрГУ, 2003. 349 с.

3. Пьер Бурдье, Роже Шартье. Социологическая «истина» причиняет страдания: интервью / пер. с фр. Н. Вокуева // Сигма : [сайт]. URL: https://syg.ma/@nikolai-vokuiev/pierburdie-sotsiologhichieskaia-istina-prichiniaiet-stradaniia (дата обращения: 23.04.2020).

4. Доброва Е. А. Льюис Нэмир - личность в истории // Россия и Британия. Вып. 3. В мире английской истории.

УДК 101.1+177.7

Науч. спец. 09.00.13

DOI: 10.36809/2309-9380-2020-27-51-54

\section{ВРАЧЕБНАЯ ОШИБКА: ФИЛОСОФСКИЙ, ЭТИКО-КУЛЬТУРНЫЙ, ПРАВОВОЙ АСПЕКТЫ ПРОБЛЕМЫ}

В статье рассматриваются философский, этико-культурный, правовой аспекты проблемы врачебной ошибки. Сравниваются этический и правовой статус врачебной ошибки. Ставится вопрос о существующих и возможных границах ответственности врача за совершенную ошибку. Утверждается, что отношение к врачебной ошибке в обществе менялось в зависимости от роли врача в культуре. Рассматривая понятие ошибки в философском и религиозном контекстах, автор статьи утверждает, что формальное медицинское право оказывается недостаточным для определения вины врача за совершенную им ошибку. В статье предлагается переместить фокус внимания С внешних факторов на внутреннюю этическую позицию врача.

Ключевые слова: врачебная ошибка, право, этика, нравственность.
Памяти академика В. Г. Трухановского. М. : Наука, 2002. C. 260-268.

5. Юмашева Ю. Ю. Историография просопографии // Изв. Урал. гос. ун-та. 2005. № 39. С. 95-127.

6. Эриксон Э. Молодой Лютер. Психоаналитическое историческое исследование. М. : Моск. филос. фонд «Медиум», 1996. $506 \mathrm{c.}$

7. Могильницкий Б. Г., Николаева И. Ю., Гульбин Г. К. Американская буржуазная «психоистория» : критический очерк. Томск : Изд-во Том. ун-та, 1985. 273 с.

8. Ле Гофф Ж. Людовик IX Святой / пер. В. Матузовой. М. : Ладомир, 2001. 800 c.

9. Дэвис Н. 3. Дамы на обочине. Три женских портрета XVII века / пер. с англ. Т. Доброницкой. М. : Новое литературное обозрение, 1999. 400 с.

10. Репина Л. П. Историческая биография и «новая биографическая история» // Диалог со временем: альманах интеллектуальной истории. М., 2001. Спец. вып. Историческая биография и персональная история. С. 5-11.

11. Бурдье П. Практический смысл / пер. с фр. А. Т. Бикбов, К. Д. Вознесенская, С. Н. Зенкин, Н. А. Шматко ; отв. ред. пер. и послесл. Н. А. Шматко. СПб. : Алетейя, 2001. $562 \mathrm{C}$.

12. Davis N. Z. A Life of Learning (Charles Homer Haskins Prize Lecture) // American Council of Learned Societies occasional paper. 1997. № 39. URL: https://publications.acls. org/OP/Haskins_1997_NatalieZemonDavis.pdf (дата обращения: 22.04.2020).

(C) Синельникова Г. А., 2020

\title{
MEDICAL ERROR: \\ PHILOSOPHICAL, ETHICAL AND CULTURAL, LEGAL ASPECTS OF THE PROBLEM
}

The article discusses philosophical, ethical and cultural, legal aspects of the problem of medical error. The article compares the ethical and legal status of medical error. The study addresses the question of present and possible bounds of doctor's liability for making errors. The author states that attitude to medical errors in society had changed depending on the doctor's role in the culture. Considering the concept of error in philosophical and religious contexts, the author states that formal medical law is not sufficient to determine the doctor's guilt for his error. The article proposes to shift the focus of attention from external factors to the internal ethical position of the doctor.

Keywords: medical error, law, ethic, morality. 


\section{ФИЛОСОФИЯ}

Врачебная ошибка остается актуальной проблемой современной медицины. Официальную статистику врачебных ошибок никто не ведет, но, по подсчетам общественных организаций, ошибки медиков обходятся очень дорого. Они уносят каждый год жизни десятков тысяч человек и приводят к тяжелым осложнениям здоровья у более семидесяти тысяч человек в год [1]. При этом на первом месте стоят ошибки врачей-стоматологов, второе место занимает гибель или увечье роженицы или новорожденного в родильном доме, на третьем месте находятся ошибки врачей-хирургов.

Хотя у данной проблемы есть множество аспектов, на наш взгляд, основной вопрос касается оценки действий врача и тех последствий, к которым данные действия привели. Например, врач-педиатр не прислушался к словам матери, когда она жаловалась на продолжительные головные боли у ребенка. В результате бездействия врача у ребенка случился инсульт.

Можно ли здесь говорить о врачебной ошибке с позиций формального медицинского права? Как оценить поступок врача в рамках традиционной медицинской этики? И насколько данная оценка важна ребенку, утратившему все двигательные навыки, и его матери, испытывающей чувство вины за то, что она не смогла самостоятельно увидеть признаки инсульта и вовремя его предотвратить? Все эти вопросы не имеют однозначного ответа в силу специфики самой врачебной деятельности, которая представляет собой сложный конгломерат юридических правил, этических стандартов и собственно фигуры врача, который осуществляет эту деятельность.

«То, что врач нередко заблуждается при распознавании болезней, - явление понятное и до известной степени пока неизбежное ввиду целого ряда объективных трудностей медицины», - отметил академик И. В. Давыдовский, предложивший одно из наиболее распространенных толкований врачебной ошибки [2, с. 8]. Он полагал, что «врачебные ошибки являются досадным браком во врачебной деятельности» [2, с. 9], возникающим вследствие добросовестного заблуждения врача при выполнении им профессиональных обязанностей: «Мы не можем представить себе врача, даже немолодого, который бы в своей деятельности мог безошибочно определить любое заболевание или столь же безошибочно ориентироваться в выборе способа лечения» [2, с. 3]. Однако врачебные ошибки имеют особый статус среди прочих дефектов врачебной деятельности: они исключают умышленные преступные действия - небрежность, халатность, невежество.

Данное определение наиболее часто используется в основе других определений, которые встречаются в медицинской литературе, например: «врачебная ошибка - неправильное деяние врача в профессиональной деятельности при отсутствии вины»; «врачебная ошибка - неправильное действие (или бездействие) врача, имеющее в своей основе несовершенство современной науки, незнание или неспособность использовать имеющиеся знания на практике» [3, с. 66].

Интересно, что данное определение врачебной ошибки подразумевает отсутствие вины врача, если он руко- водствовался основным этическим принципом медицины со времен Гиппократа - primum non nocere (прежде всего не навреди). С одной стороны, это объясняется самой природой медицинской деятельности. Каждый организм обладает определенным набором физиологических особенностей, которые могут по-разному себя проявить даже при соблюдении всех предусмотренных норм и правил, применимых при оказании медицинской помощи.

В большинстве случаев врачу действительно сложно прогнозировать абсолютный результат при проведении операции, назначении медикаментозной терапии или постановке диагноза. Зачастую врачи не могут гарантировать своим пациентам отсутствие неблагоприятных последствий. Потенциальный вред от действий врача учитывается, и пациент дает своё добровольное согласие на процедуру, подтверждая, что он информирован обо всех возможных побочных эффектах, вплоть до летального исхода.

С другой стороны, дает ли такая неопределенность врачу право на ошибку? Можно ли говорить о презумпции невиновности врача, если он причинил вред по неосторожности или незнанию?

История знает законы, которые сурово карали врачей за совершенные ими ошибки независимо от причины их возникновения. Например, в одном из древнейших сохранившихся правовых памятников, Кодексе законов Хаммурапи, был параграфр об ответственности врача, причинившего вред здоровью человека: «Если лекарь сделал человеку тяжелую операцию бронзовым ножом и убил этого человека или же он вскрыл бельмо у человека бронзовым ножом и выколол глаз человеку, то ему должны отрубить кисть руки» $[4$, с. 24]. В России в одном из указов 1686 г. лекари предупреждались о том, что, если кто-нибудь из них специально или по неосторожности убьет пациента и об этом узнают, наказанием будет смертная казнь.

Постепенное смягчение наказаний врача за совершенную врачебную ошибку произошло в XX в., когда участились случаи привлечения врачей к уголовной ответственности, и в медицинском сообществе возник вопрос о правовой защите врачей. В 20-е гг. XX в. было предложено создать специальные комиссии для анализа случаев врачебных ошибок, их изучения с целью принятия дальнейшего решения о наличии или отсутствии вины врача. Интересно, что против такой меры выступали юристы, наставая на применении к врачам общих правовых норм.

Наконец, в середине XX в. оформилась практика судебно-медицинской экспертизы в случаях причинения вреда здоровью пациенту ввиду неправильных действий медицинских работников.

Сегодня врача можно привлечь к гражданско-правовой ответственности в соответствии с Федеральным законом от 21 ноября 2011 г. № 323-Ф3 «Об основах охраны здоровья граждан в Российской Федерации». В первоначальной редакции данного закона можно было встретить норму о профессиональной ошибке медицинского работника, которой признавалось добросовестное заблуждение медицинского работника при отсутствии прямого или косвенного (халатность, небрежность) умысла, направленного на причинение вреда жизни и здоровью пациента. Впоследствии 
статья о врачебной ошибке была исключена из проекта закона, и на сегодняшний день термин «врачебная ошибка» отсутствует в законодательстве Российской Федерации. Следовательно, в правовом поле его нет.

Мы помним, что право есть необходимый минимум морали. Поэтому возникает закономерный вопрос о моральном статусе врачебных ошибок, которые продолжают совершаться во врачебной практике. И здесь мы вынуждены признать, что язык правовых норм сводит врачебную ошибку к оценке фризического и морального вреда, причиненного пациенту действиями или бездействием врача, без учета внутренней мотивации самого врача. Это зачастую заставляет даже добросовестных врачей отказываться от рискованных действий, дабы не иметь проблем с законом.

Ужесточение наказаний за ненадлежащую медицинскую помощь вместе с размытым определением правомерности осуществления медицинскими работниками своих профессиональных действий приводит к тому, что любое неформальное решение врача становится рискованным. Сегодня к ятрогении может быть причислено любое действие врача, если он выходит за границы, установленные порядком оказания медпомощи.

Согласно мнению П. Габай, юрисконсульта по медицинскому праву, всё больше опытных врачей и медицинской молодежи не рискуют принимать ответственные решения [5]. Возникает парадоксальная ситуация: закон защищает интересы пациентов, но стирает само понятие личной ответственности врача, поскольку ответственность подразумевает личное участие врача в принятии решения. В результате внутренний самоконтроль врача замещается внешним контролем правовых норм, и у врача закономерно возникает соблазн переложить на пациента и принятие решения, и ответственность за него. Об этой тенденции в медицине писал К. Дернер: «Контроль извне, неразрывно связанный с недоверием ко мне, принуждает меня уже из чувства собственного достоинства постоянно избегать этого контроля и обходить его. Как следствие, сами медики являются сегодня вдохновленными поборниками прав самоопределения пациентов» [6, с. 37].

На наш взгляд, современная ситуация в медицине стала закономерным результатом её перехода из сферы социальной помощи в сферу оказания услуг. В культуре потребления пациент из человека страдающего, нуждающегося в помощи, превратился в потребителя медицинской услуги. И как потребитель медицинской услуги он может диктовать врачу свои требования, тем самым превращая врача из субъекта медицинской деятельности в объект реализации собственных притязаний. В данной системе роль врача сводится к пассивному исполнению воли пациента. Врач уже не подобен Богу, как это было в традиции патернализма. Он скромный статист.

Но как только я становлюсь объектом чьих-то притязаний, я автоматически перестаю нести ответственность за действие, которое совершаю. В этот момент я перестаю быть автором собственного действия и становлюсь исполнителем чужой воли. Я совершаю действие, но, строго говоря, меня в этом действии нет. Мои действия перестают быть личностным актом, поступком в том смысле, как это слово понимал М. М. Бахтин: «...вся жизнь в целом может быть рассмотрена как некоторый сложный поступок: я поступаю своей жизнью, каждый отдельный акт и переживание есть момент моей жизни-поступления» [7, с. 12]. Такой отказ от субъектности врача в отношениях «врач - пациент» означает врачебную деятельность в условиях отказа от собственной системы норм и ценностей и, как следствие, приводит к отказу признавать ошибки как таковые.

Нам представляется симптоматичным исчезновение понятия врачебной ошибки из правового поля, поскольку современная формализация фигуры врача и его действий в медицинской практике в определенном смысле исключает не только ответственность врача, но и само понятие ошибки. Если поступок поступают, то ошибку ошибаются, и это личностный акт. Как поступок может быть и «поступок-мысль, и поступок-чувство, и поступок-дело» [6, с. 50], так и ошибка может быть на уровне мышления, чувства или действия. В любом случае от врача требуется совершить внутренний, не формальный выбор, что возможно только в рамках неформальных отношений между врачом и пациентом.

Сама этимология слова «ошибка» в русском языке указывает на субъектность: «ошибиться» означает «нанести удар мимо цели»; таким образом, слово «ошибка» понималось как промах, неточное попадание при ударе. Интересно, что подобное толкование ошибки точно совпадает с понятием греха в христианстве. Если убрать моральную оценку греха как отпадения человека от Бога и несоответствия человека цели его существования, для нас эта аналогия важна, поскольку указывает на личностное участие человека, его активность. Таким образом, ошибка возможна лишь в границах субъектных отношений, когда участник этих отношений делает свой выбор и берет на себя ответственность.

Только в этом случае врач выступает как субъект, каждый раз совершающий свой нравственный выбор. И если каждый из участников этого процесса видит в Другом не средство, но цель, мы можем при оценке того или иного действия врача полагаться на его цели. Это не дает врачу презумпцию невиновности, но делает его субъектом этики. Выдающийся хирург Н. М. Амосов в дневнике «Мысли и сердце» писал: «Надо называть вещи своими именами. Я много думал и передумываю снова и снова. Тысячи сложных и сложнейших операций и... довольно много смертей. Среди них немало таких, в которых я прямо виноват. Нет, нет, это не убийства! Все во мне содрогается и протестует. Ведь я сознательно шел на риск для спасения жизни» $[8$, c. 6].

Здесь мы видим, как врач оценивает свою деятельность с точки зрения её цели - спасения жизни пациента. Сама цель заставляет врача идти на риск, брать на себя ответственность и отвечать за свой поступок перед пациентами и своей совестью. В решении этой трудной задачи, в этом нравственном выборе проявляется альтруизм врача с сопутствующей ему самоотверженностью [9, с. 651]. И, похоже, это единственный возможный путь: «В этических конфрликтах человек может встретить только субъективные решения. Никто не может за него сказать, где каждый раз проходит 


\section{ФИЛОСОФИЯ}

крайняя граница настойчивости в сохранении и развитии жизни» [10, с. 79].

Таким образом, ошибка во врачебной деятельности - это не столько добросовестное заблуждение врача при исполнении им служебных обязанностей. Скорее это следствие личностного субъективного выбора врача, который направляет все силы на благо пациента. Это следствие личностного поступка и принятия на себя личной ответственности за возможный «промах».

Неслучайно в XIX в. в России наиболее выдающие врачи (Н. И. Пирогов, С. П. Боткин) выступали за публичное признание врачом совершенных им ошибок. Эталоном отношения врача к собственным ошибкам следует считать слова Н. И. Пирогова: «Я считал... своим священным долгом откровенно рассказать читателям о своей врачебной деятельности и её результатах, так как каждый добросовестный человек, особенно преподаватель, должен иметь своего рода внутреннюю потребность возможно скорее обнародовать свои ошибки, чтобы предостеречь от них других людей, менее сведущих» [11, с. 13-14].

Подобно тому, как вера может быть только личностным актом, врачебная этика как практическая фрилософия всякий раз реализуется в отдельном поступке врача. Надо только не забывать, что неизбежное зло врачебных ошибок не искупается добрыми намерениями. По словам А. Швейцера, «чистая совесть - это изобретения дьявола» [10, с. 229]. Поэтому каждый раз, принимая решение о допустимых границах риска, врач должен спрашивать себя, насколько потенциальный риск его поступка оправдан целью спасения пациента. Тогда, возможно, отношения врача и пациента снова станут субъект-субъектными, а медицина - сферой социальной помощи страдающему человеку.
1. Минздрав сообщил о 70 тыс. случаев осложнений в год из-за врачебных ошибок // Интерфакс. Россия : [сайт]. URL: https://www.interfax.russia/694577 (дата обращения: 10.04.2020)

2. Давыдовский И. В. Врачебные ошибки // Советская медицина. 1941. № 3. С. 3-10.

3. Лесниченко А. М. Врачебная ошибка // Вопросы науки и образования. 2018. № 13-25. С. 66-78.

4. Тураев Б. Законы Хаммурапи. М. : Директ-Медиа, 2018. $124 \mathrm{C}$.

5. Ципенюк О., Габай П. Иногда врачи просто не имеют права помогать // Огонек. 2018. № 42. C. 30. URL: https://www. kommersant.ru/doc/3785423 (дата обращения: 10.04.2020).

6. Дернер К. Хороший врач. Учебник основной позиции врача. М. : Алетейя, 2006. 544 с.

7. Бахтин М. М. К философии поступка // Бахтин М. М. Работы 1920-х годов. Киев : Next, 1994. С. 9-68.

8. Амосов Н. М. Мысли и сердце. М. : Диалектика, 2019. $288 \mathrm{c}$.

9. Гидлевский А. В., Максименко Л. А. Альтруизм и эгоизм как базовые детерминанты бытия человека // Философские науки. 2014. № 6. С. 649-653.

10. Швейцер А. Культура и этика. М. : Прогресс, 1973. $343 \mathrm{c}$.

11. Пирогов Н. И. Анналы хирургического отделения клиники имп. Дерптского университета, год издания I, Дерпт, 1837 (перевод с немецкого Г. А. Рейнберга) // Собр. соч. : в 8 т. Т. 2. Труды по клинической хирургии (1837-1839). М. : Медгиз, 1959. С. 9-281.

(c) Чалдышкина М. В., 2020 